\title{
Sufficiency ranges and crop nutrient removals for peppermint (Mentha X piperita L.) established from field and pot fertilizer experiments
}

\section{Margarida Arrobas, Isabel Q. Ferreira, Sandra Afonso \& M. Ângelo Rodrigues}

To cite this article: Margarida Arrobas, Isabel Q. Ferreira, Sandra Afonso \& M. Ângelo Rodrigues (2018): Sufficiency ranges and crop nutrient removals for peppermint (Mentha X piperita L.) established from field and pot fertilizer experiments, Communications in Soil Science and Plant Analysis, DOI: 10.1080/00103624.2018.1474909

To link to this article: https://doi.org/10.1080/00103624.2018.1474909

\section{曲 Published online: 21 May 2018.}

\section{Submit your article to this journal ¿}

Џلl Article views: 2

Q View related articles ¿

View Crossmark data ¿ 


\title{
Sufficiency ranges and crop nutrient removals for peppermint (Mentha X piperita L.) established from field and pot fertilizer experiments
}

\author{
Margarida Arrobas (D), Isabel Q. Ferreira (D), Sandra Afonso (D, and M. Ângelo Rodrigues (D) \\ Mountain Research Centre - Polytechnic Institute of Bragança, Campus de Santa Apolónia, Bragança, Portugal
}

\begin{abstract}
Peppermint is an important aromatic and medicinal plant used across the world in pharmaceutical, cosmetic and food industries. However, there is a lack of agronomic research on this crop which hinders the implementation of best agricultural practice at farm level. Plant analysis, for instance, cannot be used as a tool to implement a suitable fertilizer recommendation program, since sufficiency ranges and crop nutrient removals have not yet been established. Thus, the main objectives of the present work were to assess the response of peppermint to varying nitrogen $(N)$, phosphorus $(P)$, potassium $(K)$ and boron $(B)$ rates, to establish sufficiency ranges from macro, micronutrients and SPAD-readings and to estimate crop nutrient removals in the aboveground biomass. Field trials and pot experiments were conducted from 2013 to 2015 in a wide range of conditions involving $12 \mathrm{~N}, \mathrm{P}, \mathrm{K}$ or B fertilizer trials and a total of 48 cuts of biomass. Nitrogen fertilization increased dry matter yield of peppermint on the vast majority of sampling dates. In contrast, $\mathrm{P}, \mathrm{K}$, or B did not produce a significant effect on dry matter yield in any of the experiments. The sufficiency ranges set for macronutrients $\mathrm{N}, \mathrm{P}, \mathrm{K}, \mathrm{Ca}$ and $\mathrm{Mg}$ are respectively $32.0-42.0,1.2-4.5$, $10.0-30.0,7.0-23.0$, and $4.0-10.0 \mathrm{~g} \mathrm{~kg}^{-1}$. Those for micronutrients $B$, copper $(\mathrm{Cu})$, iron $(\mathrm{Fe})$, zinc $(\mathrm{Zn})$, and manganese $(\mathrm{Mn})$ are respectively $20-200,5-25$, $100-600,25-300$, and $30-200 \mathrm{mg} \mathrm{kg}^{-1}$. Sufficiency range for SPAD-readings is $45-50$ SPAD units. All these ranges were established for the commercial harvesting date. The amounts of $\mathrm{N}, \mathrm{P}, \mathrm{K}$, calcium $(\mathrm{Ca})$, and magnesium $(\mathrm{Mg})$ removed in aboveground biomass are respectively $22.7,1.6,26.4,16.4$ and $4.8 \mathrm{~kg}$ $\mathrm{Mg}^{-1}$ of dry biomass.
\end{abstract}

\section{ARTICLE HISTORY}

Received 27 February 2017

Accepted 8 April 2018

\section{KEYWORDS}

Dry matter yield; leaf nutrient concentration; plant analysis; threshold values

\section{Introduction}

Mentha x piperita L., commonly known as peppermint, is a hybrid resulting from a cross between Mentha spicata L. (spearmint) and Mentha aquatica L. (watermint). Peppermint is a herbaceous rhizomatous perennial plant, native to Europe and the Middle East which can be found wild with its parent species, typically in moist habitats (Cunha, Ribeiro, and Roque 2007; Grünwald and Jänicke 2009). As a crop it reproduces only vegetatively by rhizomes or by cuttings prepared from the shoots, since it is usually sterile, producing no seeds.

Peppermint is an important aromatic and medicinal plant used across the world in pharmaceutical, cosmetic and food industries. Its most abundant and valuable constituent is menthol (Deschamps et al. 2012). There are a large number of everyday products containing peppermint, such as toothpastes, mouthwashes, chewing gums, peppermint candies, shampoos, soaps and skin care products. It is also largely used in confectionery, ice-creams and beverages (Abdou and 
Mohamed 2014; Cunha, Ribeiro, and Roque 2007). In medicine, peppermint has been studied due to its potential antibacterial properties (Ghayempour and Mortazavi 2014; Sujana et al. 2013), to act as an antispasmodic agent (Imagawa et al. 2011; Yamamoto et al. 2006), to treat irritable bowel syndrome (Cash, Epstein, and Shah 2016; Haber and El-Ibiary 2016), to relieve nausea and vomiting symptoms (Sites et al. 2014) or to improve athletic performance (Meamarbashi and Rajabi 2013).

There is also some agronomic research on this crop reporting the effect of planting date (Piccaglia et al. 1993; Singh, Singh, and Singh 1998), harvesting time (Rohloff et al. 2005), plant spacing (Gopichand et al. 2013; Verma et al. 2013) and propagation methods (Ringuelet et al. 2003) on biomass yield and/or essential oil yield and composition. Some agronomic research has also been focused on fertilization strategies, probably because of the marked effect on dry matter yield and plant composition resulting from the use of fertilizers. Studies have been carried out to test forms and rates of mineral fertilizers (Arango et al. 2012; Alkire and Simon 1996; Deschamps et al. 2012; Jeliazkova et al. 1999; Piccaglia et al. 1993; Valmorbida and Boaro 2007), organic amendments (Abdou and Mohamed 2014; Gopichand et al. 2013) or the combination of mineral and organic materials (Ram et al. 2012; Sheykholeslami et al. 2015). In most studies, however, the agronomic component is usually quite limited and only supports an analytical part which tends to be the heart of the study. They are rarely comprehensive studies focused on the agronomic aspects of the crop.

The shortage of agronomic data hinders the implementation of the agricultural practice at farm level. In spite of the economic importance and worldwide distribution of this crop, as far as we know, there have not yet been established critical levels or leaf nutrient concentration standards for this species. Bryson et al. (2014) reported sufficiency ranges for more than 2,000 cultivated species but they did not include peppermint. This means that plant analysis cannot currently be used as a diagnostic tool to monitor the nutritional status of the crop. Nor can plant analysis be used as a tool in fertilizer programs.

The main objectives of the present work are: i) assessing the effect of the application of nitrogen $(\mathrm{N})$, phosphorus $(\mathrm{P})$, potassium $(\mathrm{K})$ or boron $(\mathrm{B})$ as fertilizers on dry matter yield of peppermint; ii) establishing threshold values or sufficiency ranges for important macro and micronutrients and also SPAD-readings, the latter an $\mathrm{N}$ nutritional index determined by a portable tool which dispenses with sending plant samples to the lab; and iii) estimating crop nutrient removals, a necessary component in the fertilizer recommendation programs since it represents crop needs. Field trials and pot experiments were conducted from 2013 to 2015 in a wide range of conditions involving $12 \mathrm{~N}, \mathrm{P}$, $\mathrm{K}$ or B fertilizer trials. A total of 48 cuts of biomass were made from which dry matter yield and elemental composition of leaves and stems were determined.

\section{Material and methods}

\section{Study site and experimental designs}

The study consisted of 12 fertilization experiments carried out in the region of Bragança, NE Portugal. Four field trials were carried out during two consecutive years, in 2013 and 2014, and eight pot experiments in 2013 (1), 2014 (3) and 2015 (4).

The region benefits from a Mediterranean climate. The average annual air temperature and cumulative precipitation for the period $1971-2000$ are, respectively, $12.3^{\circ} \mathrm{C}$ and $758 \mathrm{~mm}$. Average monthly temperature and cumulative precipitation recorded during the experimental period are presented in Figure 1.

The field trial was established in a commercial field of peppermint organically managed. The farmer prepared the cultivated plot in terraces to reduce the slope and to facilitate cultivation. The soil where the field trial was carried out is a Leptosol derived from schist. Selected properties of this soil and other three used in the pot experiments were determined before the trial started. After drying $\left(40^{\circ} \mathrm{C}\right)$ and sieving ( $2 \mathrm{~mm}$ mesh), soil samples were subjected to determination of: 1 ) clay, silt and sand, by the Robinson pipette method; 2) $\left.\mathrm{pH}\left(\mathrm{H}_{2} \mathrm{O}\right) ; 3\right)$ easily oxidizable organic carbon, 


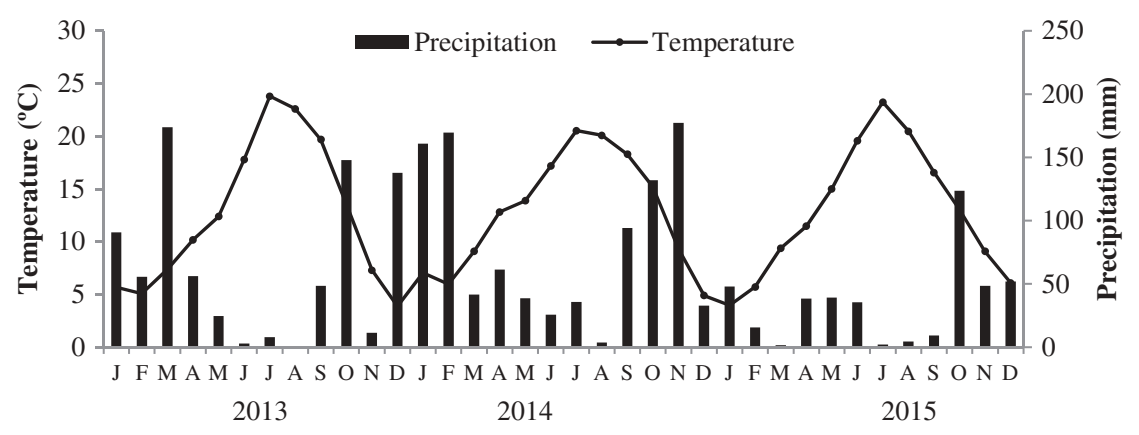

Figure 1. Average monthly temperature and cumulative precipitation during the experimental period (2013-2015) recorded in the weather station of Qta de Sta Apolónia, Bragança.

determined by the Walkley-Black method; 4) extractable $\mathrm{P}$ and $\mathrm{K}$, by using ammonium lactate solution at $\mathrm{pH} 3.7 ; 5)$ cation exchange capacity, determined by ammonium acetate, $\mathrm{pH} 7.0$, and exchangeable acidity extracted by $1 M$ potassium chloride $(\mathrm{KCl})$. Methods $1-3,5$ are fully described in van Reeuwijk (2002) and method 4 in Houba, van der Lee, and Novozamsky (1997). The results of these analyses are presented in Table 1.

The ground of the commercial field of peppermint was covered by a black plastic anti-weed mat punched with holes spaced at $40 \times 40 \mathrm{~cm}$ where the plants grow. The field experiments were arranged as completely randomized designs with four $\mathrm{N}\left(0,50,100\right.$ and $\left.150 \mathrm{~kg} \mathrm{ha}^{-1} \mathrm{yr}^{-1}\right)$, and three $\mathrm{P}\left(\mathrm{P}_{2} \mathrm{O}_{5}\right)\left(0,50\right.$ and $\left.100 \mathrm{~kg} \mathrm{ha}^{-1} \mathrm{yr}^{-1}\right), \mathrm{K}\left(\mathrm{K}_{2} \mathrm{O}\right)\left(0,50\right.$ and $\left.100 \mathrm{~kg} \mathrm{ha}^{-1} \mathrm{yr}^{-1}\right)$, and boron $(\mathrm{B} ; 0,1$, and 2 $\mathrm{kg} \mathrm{ha}^{-1} \mathrm{yr}^{-1}$ ) rates, and three replications. Each individual plot consisted of six rows $2.8 \mathrm{~m}$ long. The plots were fertilized with the nutrients corresponding to the experimental design and with those of a basal fertilization plan, consisting of $100 \mathrm{~kg} \mathrm{~N},\left(\mathrm{P}_{2} \mathrm{O}_{5}\right)$ and $\left(\mathrm{K}_{2} \mathrm{O}\right) \mathrm{ha}^{-1} \mathrm{yr}^{-1}$, and $2 \mathrm{~kg} \mathrm{~B} \mathrm{ha}^{-1} \mathrm{yr}^{-1}$. Thus, each plot received the nutrient of the experimental design plus the others of the basal fertilization plan. All the fertilizers used are authorized for organic farming. They were added to the plants as a nutrient solution split in four applications during the growing season. The commercial fertilizers used to prepare the nutrient solutions were organihum nitro ( $8 \%$ total $\mathrm{N}$ ), organihum $\mathrm{P}\left(8 \% \mathrm{P}_{2} \mathrm{O}_{5}\right)$, organihum $\mathrm{K}\left(45 \% \mathrm{~K}_{2} \mathrm{O}\right)$, fosfigen $\left(30 \% \mathrm{P}_{2} \mathrm{O}_{5}, 20 \% \mathrm{~K}_{2} \mathrm{O}\right)$ and neobor $(15 \% \mathrm{~B})$. After being prepared, the nutrient solution was poured in the holes of the mat near the plants. The field was drip-irrigated from May to September.

The pot experiment of 2013 consisted of a completely randomized design with four $\mathrm{N}$ rates $(0$, $0.45,0.90$, and $1.35 \mathrm{~g} \mathrm{pot}^{-1}$ ) and six replications (six pots). The basal fertilization plan of this experiment consisted of the application of $0.90 \mathrm{~g}\left(\mathrm{P}_{2} \mathrm{O}_{5}\right)$ and $\left.\mathrm{K}_{2} \mathrm{O}\right) \operatorname{pot}^{-1}$, and of a mixture of secondary macro and micronutrients applied as a commercial product marketed as oligomag [10\% magnesium oxide $(\mathrm{MgO}), 0.3 \% \mathrm{~B}, 18.5 \% \mathrm{SO}_{3}, 0.3 \%$ copper $(\mathrm{Cu}), 2 \%$ iron $(\mathrm{Fe}), 1 \%$ manganese $(\mathrm{Mn})$, $0.02 \%$ molybdenum (Mo), $1.6 \%$ zinc $(\mathrm{Zn})]$ at a rate of $0.08 \mathrm{~g} \mathrm{pot}^{-1}$. The fertilizers used were the same as reported for the field trial. As in the field experiment, the nutrients were added as a nutrient solution splitting the fertilization plan into four applications during the growing season. The pots

Table 1. Selected properties of the soil of the field trials (FieldT) and of those used in the pot experiments in 2013 (PotExp 2013), 2014 (PotExp 2014) and 2015 (PotExp 2015). All the soils were sampled in the $0-20 \mathrm{~cm}$ layer.

\begin{tabular}{|c|c|c|c|c|c|c|}
\hline & $\begin{array}{l}\text { Texture } \\
\text { (USDA) }\end{array}$ & $\frac{\mathrm{pH}}{\left(\mathrm{H}_{2} \mathrm{O}\right)}$ & $\frac{\text { Organic } C^{\dagger}}{\left(\mathrm{g} \mathrm{kg}^{-1}\right)}$ & $\frac{\text { Extract. } \mathrm{P}^{\ddagger}}{\left(\mathrm{mg} \mathrm{kg}^{-1}\right)}$ & $\frac{\text { Extract. } \mathrm{K}^{\ddagger}}{\left(\mathrm{mg} \mathrm{kg}^{-1}\right)}$ & $\frac{\mathrm{CEC}^{ \pm}}{\left(\mathrm{cmol}_{\mathrm{c}} \mathrm{kg}^{-1}\right)}$ \\
\hline FieldT & Sandy loam & 6.8 & 7.9 & 22.6 & 48.5 & 8.2 \\
\hline PotExp 2013 & Sandy loam & 6.5 & 14.5 & 281.5 & 132.5 & 10.7 \\
\hline PotExp 2014 & Sandy loam & 6.0 & 8.4 & 58.0 & 51.9 & 15.1 \\
\hline PotExp 2015 & Sandy loam & 6.3 & 6.8 & 41.0 & 104.0 & 17.5 \\
\hline
\end{tabular}

${ }^{\dagger}$ Walkley-Black; ${ }^{\ddagger}$ Egner-Rhiem; ${ }^{ \pm}$Ammonium-acetate, pH 7. 
were filled with $4 \mathrm{~kg}$ of dry and sieved ( $2 \mathrm{~mm}$ mesh) soil mixed with 15 g perlite $\mathrm{kg}^{-1}$ dry soil. Cuttings of 10-15 cm height were transplanted on 21 March. The pots were placed in holes in the ground lined with PVC pipe to protect the walls of the pots from direct sunlight and to prevent overheating of the rooting zone. During the growing season the pots were weeded and watered as needed to allow normal plant growth.

In 2014 three pot experiments were carried out, each consisting of a fertilization trial of N (PEN 2014), P (PEP 2014), or K (PEK 2014). They were arranged as completely randomized designs with four $\mathrm{N}\left(0,0.8,1.6\right.$ and $\left.2.4 \mathrm{~g} \mathrm{pot}^{-1}\right)$, three $\mathrm{P}\left(\mathrm{P}_{2} \mathrm{O}_{5}\right)\left(0,0.8\right.$ and $\left.1.6 \mathrm{~g} \mathrm{pot}^{-1}\right)$, and $\mathrm{K}\left(\mathrm{K}_{2} \mathrm{O}\right)(0,0.8$ and $\left.1.6 \mathrm{~g} \mathrm{pot}^{-1}\right)$ rates and six replications. The experiment of a given nutrient $(\mathrm{N}, \mathrm{P}$ and $\mathrm{K})$ received the other two as a basal fertilization plan, consisting of 1.6 g pot $^{-1}$ of $\mathrm{N},\left(\mathrm{P}_{2} \mathrm{O}_{5}\right)$ and $\left(\mathrm{K}_{2} \mathrm{O}\right)$. The $\mathrm{N}, \mathrm{P}$ and $\mathrm{K}$ pots also received $0.08 \mathrm{~g}$ of oligomag. The nutrients were supplied as a nutrient solution prepared with the fertilizers used in the field trial and pot experiment of 2013. The pots were filled with $15 \mathrm{~kg}$ of dry and sieved ( $2 \mathrm{~mm}$ mesh) soil mixed with $15 \mathrm{~g}$ perlite $\mathrm{kg}^{-1}$ dry soil. The cuttings were transplanted on 8 May. The pots were also placed in holes in the ground lined with PVC pipe. During the growing season the pots were weeded and watered as needed.

In 2015 four pot experiments were conducted, each one as a fertilization trial of N (PEN 2015), P (PEP 2015), K (PEK 2015), or B (PEB 2015). They consisted of completely randomized designs with four rates of $\mathrm{N}, \mathrm{P}\left(\mathrm{P}_{2} \mathrm{O}_{5}\right), \mathrm{K}\left(\mathrm{K}_{2} \mathrm{O}\right)\left(0,1.6,3.2\right.$ and $\left.6.4 \mathrm{~g} \mathrm{pot}^{-1}\right)$, and $\mathrm{B}\left(0,32,64\right.$, and $\left.128 \mathrm{mg} \mathrm{pot}^{-1}\right)$ and three replications. The high rate of nutrients used in this experiment [estimated as $400 \mathrm{~kg} \mathrm{~N}$, $\left(\mathrm{P}_{2} \mathrm{O}_{5}\right)$ and $\left(\mathrm{K}_{2} \mathrm{O}\right) \mathrm{ha}^{-1}$ after taken into account a planting density of 62,500 plants $\mathrm{ha}^{-1}$ ] was aimed at pushing leaf nutrient concentration to very high values, to establish the higher limit of the sufficiency ranges. The nutrients were supplied as a nutrient solution prepared with conventional fertilizers, such as ammonium nitrate $(34.5 \% \mathrm{~N})$, superphosphate $18 \%\left(18 \% \mathrm{P}_{2} \mathrm{O}_{5}\right)$, potassium chloride $\left(60 \% \mathrm{~K}_{2} \mathrm{O}\right)$, neobor $(15 \% \mathrm{~B})$ and oligomag. Nutrients not included in the experimental designs were added as a basal fertilization plan at the rates of $2.4 \mathrm{~kg} \mathrm{~N},\left(\mathrm{P}_{2} \mathrm{O}_{5}\right)$ and $\left(\mathrm{K}_{2} \mathrm{O}\right)$ pot $^{-1}$. Oligomag was applied in the $\mathrm{N}, \mathrm{P}$ and $\mathrm{K}$ experiments at a rate of $0.08 \mathrm{~g} \mathrm{pot}^{-1}$, but not in $\mathrm{B}$ experiment. Cuttings of 10-15 cm height were transplanted on 5 May. All the other procedures were similar to those reported for the pot experiments already described.

\section{Sample collection and analysis}

In the field experiment, plant samples were collected three times per year in 2013 and 2014. The dates of sampling were 15 July, 8 August, and 7 October 2013 and 16 June, 24 July, and 6 October 2014. In each cut, six plants from the inner rows of the plots were randomly selected. A subsample of young mature leaves was used for elemental analysis to serve as the standard tissue for the establishment of the sufficiency ranges. The remaining sample was separated into leaves and stems and used to estimate dry matter yield and plant nutrient recovery. The plants were cut $\sim 10 \mathrm{~cm}$ from the soil surface shortly before flowering. All tissue materials were oven dried at $65^{\circ} \mathrm{C}$, weighed and ground. Tissue analysis was performed by Kjeldahl $(\mathrm{N})$, colorimetry $(\mathrm{P}$ and $\mathrm{B})$, flame emission spectrometry $(\mathrm{K})$, and atomic absorption spectrometry (Ca, Mg, Cu, Fe, Zn, and Mn) methods (Walinga et al. 1989).

Plants of pot experiments of 2013 were cut four times during the growing season, on 7 May, 11 June, 12 August and 4 October. The dates of sampling of the pot experiments of 2014 were 17 July, 20 August, and 23 October. Those of the pot experiments of 2015 were 22 June, 5 August and 27 November. The sampling method, the pre-treatments of tissue samples and laboratory analyses were the same as reported for the field experiments.

\section{SPAD measurements}

Estimates of the relative chlorophyll content of leaves were recorded by using a Minolta SPAD leaf chlorophyll meter (model 502 plus). The device measures the transmittance of light throughout the leaf in two different wavelengths, $650 \mathrm{~nm}$ (red light, absorbed by chlorophyll pigments) and $940 \mathrm{~nm}$ 
(infrared light, not absorbed by chlorophyll), displaying chlorophyll-SPAD readings which are proportional to the chlorophyll content of the leaf. The readings were taken from the blade of fully expanded young leaves. The measurement dates were 7 October 2013 and 11 June, 24 July and 6 October 2014 in the field trials, and 22 June, 5 August and 27 October 2015 in the pot experiments.

\section{Data analysis}

The effect of the fertilizer treatments on dry matter yield of stems, leaves and total was subjected to analysis of variance (ANOVA). When significant differences among treatments occurred, the means were separated by Tukey-Kramer HSD test $(\alpha=0.05)$.

Critical nutrient concentration is defined as the point in the curve of the relationship between tissue nutrient concentration and yield below or above which there is, respectively, a high or low probability of obtaining a positive response by the crop if more nutrient is applied (Rodrigues et al. 2005). Based on the relationship between tissue nutrient concentration and yield, critical toxic (or excessive) tissue nutrient concentrations can also be defined. To establish sufficiency ranges, the tissue nutrient concentrations were divided into three classes: deficient; adequate; and excessive. The boundaries of the adequate range were set by the threshold values as defined above. In this work, when a positive crop response to a given nutrient was found, critical nutrient concentrations were determined by the graphical method of Cate-Nelson (Cate and Nelson 1971), modified by declaring the horizontal line in a fixed value (Rodrigues 2004). From the relationship between leaf nutrient concentration and relative yield, the horizontal line was fixed at $90 \%$ of relative yield, being the vertical line free to keep the greatest amount of points in the positive quadrants. The Cate-Nelson technique has widespread use since it can overcome the difficulty of obtaining a good relationship between tissue nutrient concentration and yield. Relative yields were estimated as the percentage of the maximum yield obtained in each individual experiment. The procedure allows for the removing of most of the experimental variability and comparing critical values from a wide range of conditions. For nutrients for which a response by the crop was not found, or for those not included in the experimental design, the sufficiency ranges were estimated by removing $10 \%$ of extreme higher and lower points of the scatterplot, which probably represent outliers associated with experimental error.

Crop nutrient removals were estimated from the highly productive plots of each experiment by multiplying dry matter yield and tissue nutrient concentration after plant samples had been split into leaves and stems, weighed and analyzed separately. The results were expressed per ton of dry biomass.

\section{Results}

\section{Crop response to fertilization}

Peppermint responded to fertilizer $\mathrm{N}$ application in most of the experiments (Table 2). Dry matter yields (leaves, stems and total) significantly increased with $\mathrm{N}$ rates on almost all the sampling dates of the field and pot experiments. The results of 2013 field trial were an exception. In that year, significant differences in dry matter yield among fertilizer treatments were not found.

Peppermint did not respond to the application of P or K as fertilizers. Significant differences between fertilizer treatments did not occur in any of the 12 harvests performed in the three experiments (data not shown) of each nutrients. On the other hand, a negative effect on peppermint dry matter yield due to high rates of P and K used in PEP 2015 and PEK 2015 was also not recorded.

The application of $\mathrm{B}$ as a fertilizer did not increase dry matter yield of peppermint in any of the experiments. However, the use of excessive rates of B used in PEB 2015 significantly reduced peppermint dry matter yield (Table 3 ). 
Table 2. Leaf, stem and total dry matter yield of peppermint as a function of $\mathrm{N}$ fertilizer treatment presented as the sum of all harvests performed during a growing season. Data from the field trials of 2013 (FieldT 2013), and 2014 (FieldT 2014), and pot experiments of 2013 (PEN 2013), 2014 (PEN 2014) and 2015 (PEN 2015).

\begin{tabular}{|c|c|c|c|c|c|c|}
\hline & \multirow[b]{3}{*}{$\mathrm{NO}^{\ddagger}$} & \multirow[t]{2}{*}{ FieldT 2013} & FieldT 2014 & PEN 2013 & PEN 2014 & \multirow[t]{2}{*}{ PEN 2015} \\
\hline & & & \multicolumn{3}{|c|}{-—————-———-g plant $^{-1}-$ - - - - - - - } & \\
\hline & & $30.8 \mathrm{a}^{\dagger}$ & $22.4 \mathrm{~b}$ & $7.9 \mathrm{c}$ & $1.7 \mathrm{c}$ & $7.7 \mathrm{~d}$ \\
\hline \multirow[t]{4}{*}{ Leaves } & N1 & 30.9 a & $26.8 \mathrm{a}$ & $9.2 \mathrm{~b}$ & $2.6 \mathrm{~b}$ & $17.4 \mathrm{C}$ \\
\hline & N2 & $37.9 \mathrm{a}$ & $27.7 \mathrm{a}$ & $9.7 \mathrm{ab}$ & $2.8 \mathrm{~b}$ & $23.8 \mathrm{~b}$ \\
\hline & N3 & $34.7 \mathrm{a}$ & $26.4 \mathrm{a}$ & $10.3 \mathrm{a}$ & $3.5 \mathrm{a}$ & 27.7 a \\
\hline & No & $87.6 \mathrm{a}$ & $63.8 \mathrm{~b}$ & $8.5 \mathrm{c}$ & $8.0 \mathrm{~d}$ & $5.1 \mathrm{c}$ \\
\hline \multirow[t]{4}{*}{ Stems } & N1 & $75.7 \mathrm{a}$ & $100.1 \mathrm{a}$ & $18.2 \mathrm{~b}$ & $9.6 \mathrm{c}$ & $13.0 \mathrm{~b}$ \\
\hline & N2 & $88.4 \mathrm{a}$ & $104.7 \mathrm{a}$ & $23.7 \mathrm{ab}$ & $12.1 \mathrm{~b}$ & $19.3 \mathrm{a}$ \\
\hline & N3 & $70.4 \mathrm{a}$ & $96.3 \mathrm{a}$ & $25.4 \mathrm{a}$ & $13.6 \mathrm{a}$ & $19.6 \mathrm{a}$ \\
\hline & No & $118.4 \mathrm{a}$ & $86.3 \mathrm{~b}$ & $16.4 \mathrm{C}$ & $11.9 \mathrm{~d}$ & $12.8 \mathrm{C}$ \\
\hline \multirow{3}{*}{ Total } & N1 & $106.6 \mathrm{a}$ & $126.9 \mathrm{a}$ & $27.4 \mathrm{~b}$ & $14.3 \mathrm{C}$ & $30.4 \mathrm{~b}$ \\
\hline & N2 & $126.3 \mathrm{a}$ & $132.4 \mathrm{a}$ & $33.4 a b$ & $16.8 \mathrm{~b}$ & $43.1 \mathrm{a}$ \\
\hline & N3 & $105.1 \mathrm{a}$ & $132.6 \mathrm{a}$ & $35.8 \mathrm{a}$ & $18.9 \mathrm{a}$ & $47.3 \mathrm{a}$ \\
\hline
\end{tabular}

${ }^{\dagger}$ Within each column and different plant part (leaves, stems and total), means followed by the same letter are not statistically different by Fisher HSD test $(a=0.05)$.

${ }^{\ddagger} \mathrm{N}$ rates: FieldT [0 (N0), 50 (N1), 100 (N2) and 150 (N3) kg ha $\left.{ }^{-1}\right]$; PEN 2013 [0 (N0), 0.45 (N1), 0.90 (N2) and 1.35 (N3) g pot $\left.{ }^{-1}\right]$; PEN 2014 [0 (N0), 0.8 (N1), 1.6 (N2) and 2.4 (N3) g pot ${ }^{-1}$; and PEN 2015 [0 (N0), 1.6 (N1), 3.2 (N2) and 6.4 (N3) g pot $\left.{ }^{-1}\right]$.

Table 3. Leaf, stem and total dry matter yields of peppermint as a function of B fertilizer treatment presented as the sum of all harvests performed during each growing season.

\begin{tabular}{|c|c|c|c|c|}
\hline & & FieldT 2013 & FieldT 2014 & PEB 2015 \\
\hline & & \multicolumn{3}{|c|}{ 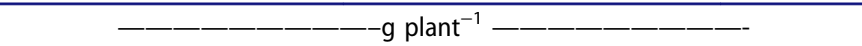 } \\
\hline & $\mathrm{B} 0^{\ddagger}$ & $35.0 \mathrm{a}^{\dagger}$ & 29.9 a & $23.8 \mathrm{a}$ \\
\hline \multirow[t]{4}{*}{ Leaves } & B1 & 36.3 a & 30.7 a & $23.3 \mathrm{a}$ \\
\hline & B2 & $40.2 \mathrm{a}$ & $34.6 \mathrm{a}$ & $24.5 \mathrm{a}$ \\
\hline & B3 & -—- & -—- & $20.7 \mathrm{~b}$ \\
\hline & B0 & $81.7 \mathrm{a}$ & $125.7 \mathrm{a}$ & $14.6 \mathrm{a}$ \\
\hline \multirow[t]{4}{*}{ Stems } & B1 & $84.7 \mathrm{a}$ & $149.8 \mathrm{a}$ & $13.8 \mathrm{a}$ \\
\hline & B2 & $93.7 \mathrm{a}$ & $122.2 \mathrm{a}$ & $14.6 \mathrm{a}$ \\
\hline & B3 & - - & -- & $12.0 \mathrm{~b}$ \\
\hline & B0 & 116.7 a & $155.6 \mathrm{a}$ & $38.4 \mathrm{a}$ \\
\hline \multirow[t]{3}{*}{ Total } & B1 & $121.0 \mathrm{a}$ & $180.5 \mathrm{a}$ & $37.1 \mathrm{a}$ \\
\hline & B2 & $133.9 \mathrm{a}$ & $156.8 \mathrm{a}$ & $39.1 \mathrm{a}$ \\
\hline & B3 & - - & - - & $32.8 \mathrm{~b}$ \\
\hline
\end{tabular}

${ }^{\dagger}$ Within each column and different plant part (leaves, stems and total), means followed by the same letter are not statistically different by Fisher HSD test $(a=0.05)$.

${ }^{\ddagger} \mathrm{B}$ rates: FieldT $\left[0\right.$ (B0), 1 (B1), 2 (B2) and 3 (B3) kg ha ${ }^{-1}$; and PEB 2015 [0 (B0), 32 (B1), 64 (B2) and 128 (B3) $\left.\mathrm{mg} \mathrm{pot}^{-1}\right]$.

\section{Critical leaf nutrient concentrations}

Critical leaf $\mathrm{N}$ concentrations were estimated for all the harvesting dates of all experiments based on the relationship between leaf $\mathrm{N}$ concentration and relative dry matter yield. Data from the harvest of 16 June of the PEN 2014 were used to exemplify the methodology and are presented in Figure 2(a). Critical leaf $\mathrm{N}$ concentration of each individual plot varied between 25 and $38 \mathrm{~g} \mathrm{~kg}^{-1}$. The average of those values, $32 \mathrm{~g} \mathrm{~kg}^{-1}$, is proposed as the lower limit of the sufficiency range for $\mathrm{N}$. The critical excessive leaf $\mathrm{N}$ concentration for each sampling date was estimated by the average of the leaf $\mathrm{N}$ concentrations of the plants fertilized with the higher $\mathrm{N}$ rate of the PEN2015. Data from the sampling date of 5 August 2015 are presented in Figure 2(b) as an example. The higher limit of the sufficiency range for $\mathrm{N}$ was estimated as the average of the critical excessive leaf $\mathrm{N}$ concentrations of all sampling dates. This value is found in $42 \mathrm{~g} \mathrm{~kg}^{-1}$.

In none of the field and pot experiments significant differences in dry matter yield between $\mathrm{P}$ or $\mathrm{K}$ fertilizer treatments were found as mentioned above. Thus, the sufficiency ranges for $\mathrm{P}$ and $\mathrm{K}$ were estimated by removing $\sim 10 \%$ of the higher and lower values of the plots prepared from the 

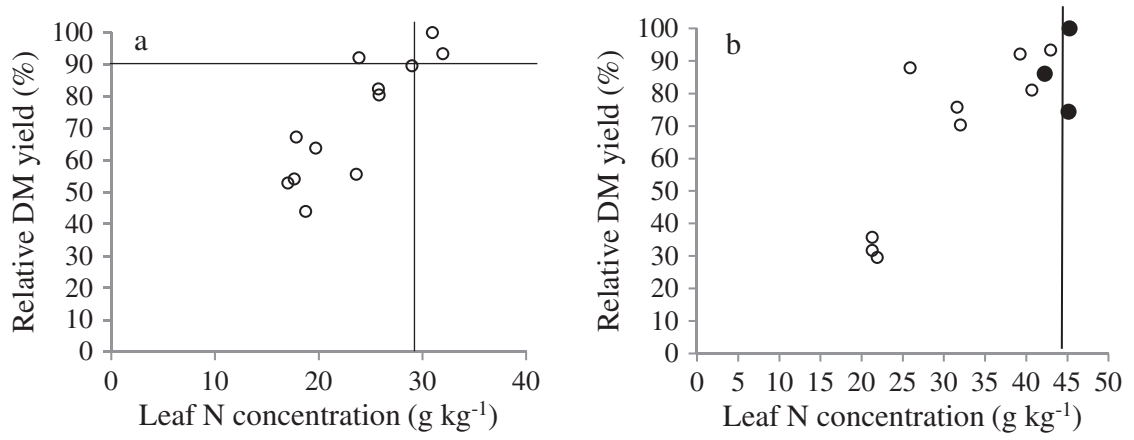

Figure 2. Critical leaf $\mathrm{N}$ concentration (a) for peppermint established from the relationship between leaf $\mathrm{N}$ concentration and relative dry matter (DM) yield (data from the harvest date of 16 June of PEN 2013), and critical excessive leaf $\mathrm{N}$ concentration (b) estimated as the average of leaf samples from the plants fertilized with the higher rates of $\mathrm{N}$ (full symbols) (data from the sampling date of 5 August of the PEN 2015).

relationship between leaf $\mathrm{P}$ or $\mathrm{K}$ concentrations and relative dry matter yields (Figure 3). These 10\% extreme values are probably outliers associated with experimental error. By using this methodology, the sufficiency ranges set for $\mathrm{P}$ and $\mathrm{K}$ were, respectively, 1.2 to $4.5 \mathrm{~g} \mathrm{~kg}^{-1}$ and 10 to $30 \mathrm{~g} \mathrm{~kg}^{-1}$.

Peppermint also did not respond to $\mathrm{B}$ application as a fertilizer. However, a significant reduction in dry matter yield was found when excessive rates of B were applied (Table 3). Thus, the critical leaf $\mathrm{B}$ concentration was estimated as the average of the leaf $\mathrm{B}$ concentrations recorded in the B0 treatments of each experiment. The value found is $20 \mathrm{mg} \mathrm{kg}^{-1}$ and is proposed as the lower limit of the sufficiency range for $\mathrm{B}$.

In PEB 2015, the higher B fertilizer treatment (B3) reduced dry matter yield of peppermint in comparison with the control and the other B fertilizer treatments (Table 3). Thus, the results of PEB 2015 were used to establish the critical excessive leaf B concentrations, by averaging the leaf B concentrations of the highest $\mathrm{B}$ treatment which produced dry matter yields not statistically different from the B0 control (Figure 4). The procedure was performed for all the three sampling dates of PEB 2015. Finally, the average of the critical excessive leaf B concentrations of all the sampling dates of PEB 2015 is proposed as the higher limit of the sufficiency range for $\mathrm{B}$. The value found is $200 \mathrm{mg} \mathrm{B} \mathrm{kg}^{-1}$.

Critical sufficiency ranges for the nutrients not included in the experimental design were estimated by removing $\sim 10 \%$ of the values away from the center of the scatterplots. These values are probably outliers associated with experimental variability which can introduce error to the


Figure 3. Sufficiency ranges for leaf $P$ (left) and $K$ (right) concentrations estimated from the relationship between leaf $P$ or $K$ concentrations and relative dry matter (DM) yields by removing $\sim 10 \%$ of the extreme higher and lower values. 




Figure 4. Critical excessive leaf $B$ concentration estimated as the average of leaf $B$ concentration in the plants of the highest $B$ treatment for which no reduction in dry matter yield occurred in comparison to B0 control (full symbols). Data from the sampling date of 22 June 2015.

interpretation of the plant analysis results. The remaining interval concentrates the mass of points, giving a high probability of the leaf concentration of a given nutrient of falling within that interval in plants of an adequate nutritional status. The sufficiency ranges established for $\mathrm{Ca}, \mathrm{Mg}, \mathrm{Cu}, \mathrm{Fe}, \mathrm{Zn}$ and $\mathrm{Mn}$ by using this approach are presented in Figure 5.

Critical SPAD readings were estimated from the relationship between SPAD readings and relative dry matter yield for several sampling dates of the field and pot experiments by using the Cate-Nelson approach. An example was provided in Figure 6(a) by using the data of 22 June of PEN 2015. The average of the critical SPAD readings of all the sampling dates was set as the lower limit of the sufficiency range for this $\mathrm{N}$ nutritional status index, and the value found was 45 . In the PEN 2015, the fertilizer treatment consisting of the highest rate of N (N3) did not produce a significant increase in dry matter yield in comparison to $\mathrm{N} 2$ treatment. The average of SPAD readings of these heavily fertilized plants were used to set the critical excessive SPAD readings. The results of the sampling date of 5 August of PEN 2015 are presented in Figure 6(b) as an example of the procedure. The average of the critical excessive SPAD readings of all the sampling dates is 50 , being the value proposed as the higher limit of the sufficiency range for SPAD readings.

Table 4 summarizes the sufficiency ranges estimated for macronutrients $\mathrm{N}, \mathrm{P}, \mathrm{K}, \mathrm{Ca}$ and $\mathrm{Mg}$, micronutrients $\mathrm{B}, \mathrm{Cu}, \mathrm{Fe}, \mathrm{Zn}$ and $\mathrm{Mn}$ and SPAD readings.

\section{Nutrient removal in dry biomass}

The aboveground biomass of peppermint was divided into leaves and stems, being both plant parts analyzed for elemental composition. Nutrient removal in the aboveground biomass was estimated from the most productive plots of each experiment, multiplying the dry biomass of each plant part by the respective nutrient concentration. The results were expressed per ton of dry biomass and are presented in Table 5.

\section{Discussion}

Nitrogen fertilization increased dry matter yield of peppermint on the vast majority of sampling dates of the field and pot experiments. Some previous studies on peppermint have also shown a significant increase in biomass and essential oil yield with applied N (Piccaglia et al. 1993; Ram et al. 2012). In contrast, Deschamps et al. (2012) tested several sources and rates of $\mathrm{N}$ on peppermint and did not find any increase in biomass and essential oil production and any improvement in oil quality. Nevertheless, $\mathrm{N}$ is an important ecological factor influencing crop growth and yield. Nitrogen does not accumulate in agricultural soils in available forms to plants, usually being applied every year to crops as fertilizers or manures. Several studies carried out in the region of Bragança 

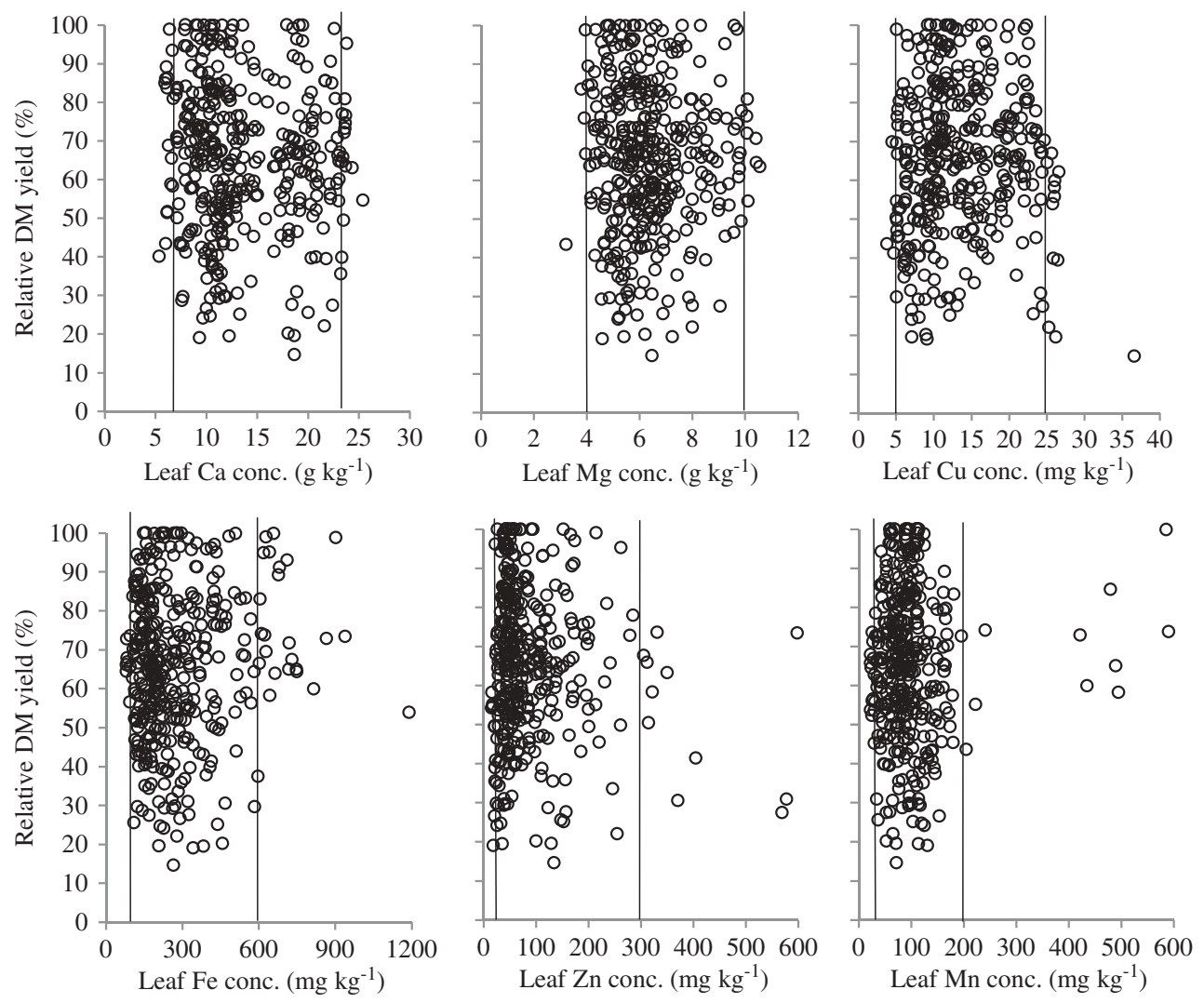

Figure 5. Sufficiency ranges established for $\mathrm{Ca}, \mathrm{mg}, \mathrm{Cu}, \mathrm{Fe}, \mathrm{Zn}$ and $\mathrm{Mn}$ from the relationship between leaf nutrient concentration and relative dry matter (DM) yield by removing $\sim 10 \%$ of the lower and higher values of each scatterplot.


Figure 6. Critical SPAD readings (a) established from the relationship between SPAD readings and relative dry matter (DM) yield by using the Cate-Nelson technique (data from the sampling date of 22 June of PEN 2015), and critical excessive SPAD readings (b) estimated as the average of SPAD readings of the plants fertilized with the highest $\mathrm{N}$ rates (full symbols) (data from the sampling date of 5 August of PEN 2015).

under similar soil and climate conditions, have shown increased yields as a response of applied $\mathrm{N}$ in a variety of crops, such as potato (Solanum tuberosum L.) (Rodrigues et al. 2005), maize (Zea mays L.) (Rodrigues et al. 2006), Jerusalem artichoke (Helianthus tuberosus L.) (Rodrigues et al. 2007), stevia [Stevia rebaudiana (Bertoni)] (Rodrigues et al. 2016), and olive (Olea europaea L.) (Rodrigues et al. 2011). In the present study, $\mathrm{P}, \mathrm{K}$ or $\mathrm{B}$ did not produce a significant effect in dry matter yield of 
Table 4. Sufficiency range established for macronutrients, micronutrients and SPAD-readings.

\begin{tabular}{lclc}
\hline Macronutrients $\left(\mathrm{g} \mathrm{kg}^{-1}\right)$ & & \multicolumn{2}{c}{ Micronutrients $\left(\mathrm{mg} \mathrm{kg}^{-1}\right)$} \\
\hline Nitrogen & $32.0-42.0$ & Boron & $20-200$ \\
Phosphorus & $1.2-4.5$ & Copper & $5-25$ \\
Potassium & $10.0-30.0$ & Iron & $100-600$ \\
Calcium & $7.0-23.0$ & Zinc & $25-300$ \\
Magnesium & $4.0-10.0$ & Manganese & $30-200$ \\
& SPAD-readings & $45-50$ & \\
\hline
\end{tabular}

Table 5. Nutrient removal (average \pm standard error) in the aboveground biomass of peppermint. Nutrient removal was estimated multiplying dry matter (DM) yield in different plant parts by its elemental composition.

\begin{tabular}{|c|c|c|c|}
\hline & \multicolumn{3}{|c|}{ Nutrient removal } \\
\hline & Leaves & Stems & Total (leaves+stems) \\
\hline Nitrogen $\left(\mathrm{kg} \mathrm{t}^{-1} \mathrm{DM}\right)$ & $10.3 \pm 1.32$ & $12.4 \pm 1.38$ & $22.7 \pm 2.55$ \\
\hline Phosphorus ( $\left.\mathrm{kg} \mathrm{t}^{-1} \mathrm{DM}\right)$ & $0.6 \pm 0.14$ & $1.1 \pm 0.34$ & $1.6 \pm 0.43$ \\
\hline Potassium ( $\left.\mathrm{kg} \mathrm{t}^{-1} \mathrm{DM}\right)$ & $8.8 \pm 1.62$ & $17.5 \pm 2.23$ & $26.4 \pm 3.44$ \\
\hline Calcium (kg t $\left.{ }^{-1} \mathrm{DM}\right)$ & $7.8 \pm 0.82$ & $8.6 \pm 0.80$ & $16.4 \pm 1.34$ \\
\hline Magnesium $\left.\mathrm{kg} \mathrm{t}^{-1} \mathrm{DM}\right)$ & $2.4 \pm 0.23$ & $2.5 \pm 0.31$ & $4.8 \pm 0.47$ \\
\hline Boron $\left(\mathrm{g} \mathrm{t}^{-1} \mathrm{DM}\right)$ & $36.6 \pm 29.19$ & $22.5 \pm 10.99$ & $59.1 \pm 37.79$ \\
\hline Iron $\left(\mathrm{g} \mathrm{t}^{-1} \mathrm{DM}\right)$ & $154.2 \pm 64.99$ & $206.7 \pm 216.10$ & $360.85 \pm 246.39$ \\
\hline Copper ( $\left.\mathrm{g} \mathrm{t}^{-1} \mathrm{DM}\right)$ & $4.2 \pm 1.03$ & $7.1 \pm 2.10$ & $11.3 \pm 3.02$ \\
\hline Zinc $\left(\mathrm{g} \mathrm{t}^{-1} \mathrm{DM}\right)$ & $21.9 \pm 7.16$ & $24.7 \pm 4.61$ & $46.6 \pm 10.23$ \\
\hline Manganese $\left(\mathrm{g} \mathrm{t}^{-1} \mathrm{DM}\right)$ & $24.0 \pm 4.69$ & $29.6 \pm 4.08$ & $53.6 \pm 7.49$ \\
\hline
\end{tabular}

peppermint in any of the experiments. However, a study from Argentina in a pot experiment has shown an increase in dry matter and essential oil production in response to $\mathrm{P}$ fertilization (Arango et al. 2012). In a study from Brazil, plants fertilized with a nutrient solution presented greater development of the aboveground biomass when fertilized with $1.5 / 3.0 \mathrm{mmol} \mathrm{L}{ }^{-1} \mathrm{~K}$ in comparison with the non-fertilized control (Valmorbida and Boaro 2007). There are also studies where different rates of compound NPK fertilizers were used and where a significant increase in dry matter yield was found with increased rates of the nutrients (Jeliazkova et al. 1999; Sheykholeslami et al. 2015). Boron was also used in a fertilization trial with peppermint (Zehtab-Salmasi, Heidari, and Alyari 2008). The nutrient was applied in a mixture with other micronutrients ( $\mathrm{Zn}$ and $\mathrm{Fe}$ ) as a foliar spray. The fertilized plants produced more dry biomass and essential oil than the non-fertilized control. Studies using organic amendments can also be found in the literature (Gopichand et al. 2013; Pegoraro et al. 2010). In these studies, the use of organic materials increased dry matter yield likely as a result of nutrient release and improvement of general soil properties.

In spite of the good number of papers dealing with peppermint fertilization that can be found in the literature, those reporting leaf $\mathrm{N}$ concentrations are very few. Hence, previous data does not exist that can help in establishing the sufficiency ranges for this crop. Alkire and Simon (1996), from an N fertilization trial, reported leaf $\mathrm{N}$ concentrations varying between 24.2 and $39.0 \mathrm{~g} \mathrm{~kg}^{-1}$. The sufficiency range proposed in this work is 32.0 to $42.0 \mathrm{~g} \mathrm{~kg}^{-1}$, which may mean that the plants of the less fertilized plots of the study of Alkire and Simon (1996) were grown under N deficiency conditions. This could make sense since the experimental designs usually included non-fertilized controls. If we try to compare the sufficiency ranges here presented to those reported by Bryson et al. (2014) for major crops, such as potatoes, maize or olive, the values are of similar magnitude but with some differences for particular species and nutrients.

Data on nutrient removal in dry biomass is an important component of the fertilizer recommendation systems since it represents a direct measure of crop needs. Nutrient removal by a crop is the result of the dry matter yield and its nutrient concentration. Comparing the values found in the literature on dry matter yield of peppermint, they can vary greatly due to general growing conditions and experimental designs (Alkire and Simon 1996; Deschamps et al. 2012; Gopichand et al. 2013; Ram et al. 2012; Singh, Singh, and Singh 1998). Thus, to avoid the 
effect of the different performance of the crop in different regions of the world, we have presented crop nutrient removals by ton of aboveground dry biomass, which allows the use of values in any part of the world.

\section{Conclusions}

Peppermint showed a strong response to $\mathrm{N}$ applied as a fertilizer in the conditions of these experiments, which should give high importance to $\mathrm{N}$ in crop management. In contrast, there was no significant response to applied P, K or B. Sufficiency ranges for 10 essential nutrients were made available, which will allow the diagnosis of the nutritional status of peppermint by means of plant analysis by comparing actual leaf nutrient concentrations with the sufficiency ranges here reported. Data on crop removal for 10 important macro and micronutrients were also provided, which can help in establishing the fertilizer recommendation programs for this crop, since crop nutrient removal provides a direct indication of crop needs.

\section{Funding}

This work was supported by the Sustainable management of medicinal and aromatic plants; [PRODER 46025].

\section{ORCID}

Margarida Arrobas (D) http://orcid.org/0000-0002-4652-485X

Isabel Q. Ferreira (D) http://orcid.org/0000-0001-5806-0063

Sandra Afonso (D) http://orcid.org/0000-0002-2464-8464

M. Ângelo Rodrigues (D) http://orcid.org/0000-0002-5367-1129

\section{References}

Abdou, M., and M. A. H. Mohamed. 2014. Effect of plant compost, salicylic and ascorbic acids on Mentha piperita L. plants. Biological Agriculture \& Horticulture 30:131-43. doi:10.1080/01448765.2014.882796.

Alkire, B. H., and J. E. Simon. 1996. Response of midwestern peppermint (Mentha x piperita L.) and native spearmint (M. spicata L.) to rate and form of nitrogen fertilizer. Acta Hort 426:537-49. doi:10.17660/ActaHortic.1996.426.58.

Arango, M. C., M. F. Ruscitti, M. G. Ronco, and J. Beltrano. 2012. Mycorrhizal fungi inoculation and phosphorus fertilizer on growth, essential oil production and nutrient uptake in peppermint (Mentha piperita L.) Inoculação com fungos micorrízicos e adubação fosfatada no crescimento, produção de óleo essencial e absorção de nutrientes em hortelã-pimenta (Mentha piperita L.). Reviews Bras Plantas Medica 14:692-99.

Bryson, G., H. A. Mills, D. N. Sasseville, J. B. Jones Jr, and A. V. Barker. 2014. Plant analysis handbook III. A guide to sampling, preparation, analysis and interpretation for agronomic and horticultural crops. Athens, GA: Micro-Macro Publishing, Inc.

Cash, B., M. Epstein, and S. Shah. 2016. A novel delivery system of peppermint oil is an effective therapy for irritable bowel syndrome symptoms. Digestive Diseases and Sciences 61:560-71. doi:10.1007/s10620-015-3858-7.

Cate, Jr, R. B., and L. A. Nelson. 1971. A simple statistical procedure for portioning soil test correlation data into two classes. Soil Science Society of America, Proceedings 35:658-60. doi:10.2136/sssaj1971.03615995003500040048x.

Cunha, A. P., J. A. Ribeiro, and O. R. Roque. 2007. Plantas aromáticas em Portugal. Caracterização e utilização. Lisboa: Fundação Calouste Gulbenkian.

Deschamps, C., R. Monteiro, M. P. Machado, H. Bizzo, and L. A. Biasi. 2012. Produção de biomassa, teor e composição do óleo essencial de Mentha x piperita L. em resposta a fontes e doses de nitrogênio Biomass production, essential oil yield and composition of Mentha x piperita L. according to nitrogen sources and doses. RevBras Plantas Medica 14:12-17. doi:10.1590/S1516-05722012000100003.

Ghayempour, S., and S. M. Mortazavi. 2014. Journal of Essential Oil Research 26:492-98. doi:10.1080/ 10412905.2014.949882.

Gopichand, R. L., M. Meena, V. L. Nag, V. K. Pathania, B. Kaul, R. D. Singh, P. S. Singh, and P. S. Ahuja. 2013. Journal of Essential Oil Research 25:354-57. doi:10.1080/10412905.2013.775674.

Grünwald, J., and C. Jänicke. 2009. Grüne apotheke (green pharmacy). München: Grafe and Unzer Verlag, GmbH.

Haber, S. L., and S. Y. El-Ibiary. 2016. Peppermint oil. American Journal of Health-System Pharmacy 73:22-26. doi:10.2146/ajhp140801. 
Houba, V. J. G., J. J. van der Lee, and I. Novozamsky. 1997. Soil analysis procedures: Other procedures. The Netherlands: Landbouwuniversiteit Wagningen.

Imagawa, A., H. Hata, M. Nakatsu, T. Anzai, Y. Yoshida, K. Kubota, T. Inokuchi, H. Jinno, and M. Ando. 2011. Journal of Gastroenterology and Hepatology 26:190-190.

Jeliazkova, E. A., V. D. Zheljazkov, L. E. Craker, B. Yankov, and T. Georgieva. 1999. NPK fertilizer and yields of peppermint, Mentha x piperita. Acta Hort 502:231-36. doi:10.17660/ActaHortic.1999.502.37.

Meamarbashi, A., and A. Rajabi. 2013. The effects of peppermint on exercise performance. Journal of the International Society of Sports Nutrition 10:15. doi:10.1186/1550-2783-10-15.

Pegoraro, R. L., M. B. Falkenberg, C. H. Voltolini, M. Santos, and M. T. Paulilo. 2010. Production of essential oils in plants of Mentha x piperita L. var. piperita (Lamiaceae) subjected to different light and substrate nutrition levels. Revista Brasil Botanic 33 (4):631-37. doi:10.1590/S0100-84042010000400011.

Piccaglia, R., V. Dellacecca, M. Marotti, and E. Giovanelli. 1993. Agronomic factors affecting the yields and the essential oil composition of peppermint (Mentha x piperita L.). Acta Horticulturae 44:29-40. doi:10.17660/ActaHortic.1993.344.4.

Ram, M., M. Singh, A. K. Prajapati, D. Ram, and G. Rawat. 2012. Towards sustainable production of peppermint (Mentha piperita L.) through integrated use of vermicompost and cowpea green manuring with synthetic nitrogen fertilization. Archives of Agronomy and Soil Science 58:293-301. doi:10.1080/03650340.2010.514266.

Ringuelet, J., E. Cerimele, C. Henning, M. Rí, and M. I. Urrutia. 2003. Propagation methods and leaf yield in peppermint (Mentha $\times$ piperita L.). Journal of Herbs, Spices \& Medicinal Plants 10:55-60. doi:10.1300/J044v10n03_06.

Rodrigues, M. A. 2004. Establishment of continuous critical levels for indices of plant and pre-sidedress soil N status in the potato crop. Communications in Soil Science and Plant Analysis 35:2067-85. doi:10.1081/LCSS-200026837.

Rodrigues, M. A., S. Afonso, I. Q. Ferreira, and M. Arrobas. 2016. Response of stevia to nitrogen fertilization and harvesting regime in Northeastern Portugal. Archives of Agronomy and Soil Science. doi:10.1080/ 03650340.2016.1230272.

Rodrigues, M. A., J. Coutinho, J. Martins, and M. Arrobas. 2005. Quantitative sidedress nitrogen recommendations for potatoes based upon crop nutritional indices. European Journal of Agronomy 23:79-88. doi:10.1016/j.eja.2004.10.001.

Rodrigues, M. A., F. Pavão, J. I. Lopes, V. Gomes, M. Arrobas, J. Moutinho-Pereira, S. Ruivo, J. E. Cabanas, and C. M. Correia. 2011. Olive yields and tree nutritional status during a four year period without nitrogen and boron fertilization. Communications in Soil Science and Plant Analysis 42 (7):803-14. doi:10.1080/00103624.2011.552656.

Rodrigues, M. A., A. Pereira, J. E. Cabanas, L. Dias, J. Pires, and M. Arrobas. 2006. Crops use-efficiency of nitrogen from manures permitted in organic farming. European Journal of Agronomy 25:328-35. doi:10.1016/j.eja.2006.07.002.

Rodrigues, M. A., L. Sousa, J. E. Cabanas, and M. Arrobas. 2007. Tuber yield and leaf mineral composition of Jerusalem artichoke (Helianthus tuberosus L.) grown under different cropping practices. Spanish Journal of Agricultural Research 5:545-53. doi:10.5424/sjar/2007054-275.

Rohloff, J., S. Dragland, R. Mordal, and T.-H. Iversen. 2005. Effect of harvest time and drying method on biomass production, essential oil yield, and quality of peppermint (Mentha x piperita L.). Journal of Agricultural and Food Chemistry 53:4143-48. doi:10.1021/jf047998s.

Sheykholeslami, Z., M. Almdari, S. Qanbari, and M. Akbarzadeh. 2015. Effect of organic and chemical fertilizers on yield and yield components of peppermint (Mentha piperita L.). American Journal of Experimental Agriculture 6:251-57. doi:10.9734/AJEA/2015/14953.

Singh, V. P., M. Singh, and D. V. Singh. 1998. Growth, yield and quality of peppermint (Mentha x piperita L.) as influenced by planting time. Journal of Herbs, Spices \& Medicinal Plants 5:33-39. doi:10.1300/J044v05n03_05.

Sites, D. S., N. T. Johnson, J. A. Miller, P. H. Torbush, J. S. Hardin, S. S. Knowles, J. Nance, T. H. Fox, and R. C. Tart. 2014. Controlled breathing with or without peppermint aromatherapy for postoperative nausea and/or vomiting symptom relief: A randomized controlled trial. Journal of Perianesthesia Nursing 29:12-19. doi:10.1016/j.jopan.2013.09.008.

Sujana, P., T. M. Sridhar, P. Josthna, and C. V. Naidu. 2013. Antibacterial activity and phytochemical analysis of \&lt; i\&gt;Mentha piperita\&lt;/i\&gt; L. (Peppermint)_An important multipurpose medicinal plant. American Journal of Plant Sciences 4:77-83. doi:10.4236/ajps.2013.41012.

Valmorbida, J., and C. S. F. Boaro. 2007. Growth and development of Mentha piperita L. in nutrient solution as affected by rates of potassium. Brazilian Archives of Biology and Technology 50:379-84. doi:10.1590/S151689132007000300003.

van Reeuwijk, L. P. 2002. Procedures for soil analysis. Technical Paper 9. ISRIC. Wageningen, The Netherlands: FAO.

Verma, R. K., A. Chauhan, R. S. Verma, L.-U. Rahman, and A. Bisht. 2013. Improving production potential and resources use efficiency of peppermint (Mentha piperitaL.) intercropped with geranium (Pelargonium graveolensL. Herit ex Ait) under different plant density. Industrial Crops and Products 44:577-82. doi:10.1016/j.indcrop.2012.09.019.

Walinga, I., W. van Vark, V. J. G. Houba, and J. J. van der Lee. 1989. Soil and plant analysis, part 7: Plant analysis procedures. Wageningen, the Netherlands: Department of Soil Science and Plant Nutrition, Wageningen, Agricultural University.

Yamamoto, N., Y. Nakai, N. Sasahira, K. Hirano, T. Tsujino, H. Isayama, Y. Komatsu, M. Tada, H. Yoshida, T. Kawabe, N. Hiki, M. Kaminishi, H. Kurosaka, and M. Omata. 2006. Journal of Gastroenterology and Hepatology 21:1394-98.

Zehtab-Salmasi, S., F. Heidari, and H. Alyari. 2008. Effects of microelements and plant density on biomass and essential oil production of peppermint (Mentha piperita L.). Plant Science Research 1:24-26. 